\title{
Counter-referral in Emergency Care Units: discourse of the collective speech
}

\author{
Contrarreferência em Unidade de Pronto Atendimento: discurso do sujeito coletivo \\ Contrarreferencia en Unidades de Atención de Urgencias: discurso del sujeto colectivo
}

Patrícia Madalena Vieira Hermida'

Eliane Regina Pereira do Nascimento' ORCID: 0000-0003-2215-4222

Maria Elena Echevarría-Guanilo' ORCID: 0000-0003-0505-9258

Selma Regina de Andrade' ORCID: 0000-0001-7449-6860

Ângela Maria Blatt Ortiga" ORCID: 0000-0003-1602-1984

'Universidade Federal de Santa Catarina. Florianópolis, Santa Catarina, Brazil.

"Secretaria Estadual de Saúde de Santa Catarina. Florianópolis, Santa Catarina, Brazil.

How to cite this article: Hermida PMV, Nascimento ERP, Echevarría-Guanilo ME, Andrade SR, Ortiga AMB. Counter-referral in Emergency

Care Units: discourse of the collective speech. Rev Bras Enferm [Internet]. 2019;72(Suppl 1):143-50. [Thematic Issue: Work and Management in Nursing]. DOI: http://dx.doi.org/10.1590/0034-7167-2018-0023

\begin{abstract}
Corresponding Author:
Patrícia Madalena Vieira Hermida

E-mail: patymadale@yahoo.com.br
\end{abstract}

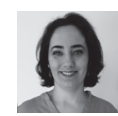

Submission: 01-27-2018

Approval: $04-20-2018$

\begin{abstract}
Objective: To describe the facilities and difficulties of the counter-referral of an Emergency Care Unit in Santa Catarina State. Method: Descriptive, qualitative study, with the participation of three nurses and 17 physicians. The data were collected through a semi-structured interview and analyzed using the Discourse of the Collective Subject technique. For the theoretical basis, the Política Nacional de Atenção às Urgências (National Policy of Emergency Care) and the Rede de Atenção às Urgências (Network of Care to the Emergencies) was used. Results: The facilities of the counter-referral correspond to the strategies of communication with the Primary Care: embracement; good interpersonal relationships; and electronic medical record network. The difficulties are related to the deficiencies of Primary Care and specialized services, such as the insufficient number of physicians and the delay in scheduling consultations and more complex exams. Final considerations: The difficulties highlighted indicate significant challenges of the local health system in the search for integration between emergency care points.

Descriptors: Health Services Research; Emergency Medical Services; Referral and Consultation; Nursing; Emergency Nursing.
\end{abstract}

\section{RESUMO}

Objetivo: Descrever as facilidades e dificuldades da contrarreferência de uma Unidade de Pronto Atendimento do estado de Santa Catarina. Método: Estudo descritivo, qualitativo, com a participação de três enfermeiros e 17 médicos. Os dados foram coletados por meio de entrevista semiestruturada e analisados com a técnica do Discurso do Sujeito Coletivo. Para o embasamento teórico, se utilizou a Política Nacional de Atenção às Urgências e a Rede de Atenção às Urgências. Resultados: As facilidades da contrarreferência correspondem às estratégias de comunicação com a Atenção Básica: acolhimento; boas relações interpessoais; e prontuário eletrônico em rede. As dificuldades estão relacionadas às deficiências da Atenção Básica e dos serviços especializados, como o quantitativo insuficiente de médicos e a demora no agendamento de consultas e de exames mais complexos. Considerações finais: As dificuldades evidenciadas indicam expressivos desafios do sistema de saúde local na busca da integração entre os pontos de atenção às urgências.

Descritores: Pesquisa sobre Serviços de Saúde; Serviços Médicos de Emergência; Encaminhamento e Consulta; Enfermagem; Enfermagem em Emergência.

\section{RESUMEN}

Objetivo: Describir las facilidades y dificultades de la contrarreferencia de una Unidad de Atención de Urgencias del estado de Santa Catarina. Método: Estudio descriptivo, cualitativo, con la participación de tres enfermeros y 17 médicos. Los datos fueron recolectados por medio de entrevista semiestructurada y analizados con la técnica del Discurso del Sujeto Colectivo. Para el basamento teórico, se utilizó la Política Nacional de Atenção às Urgências (Política Nacional de Atención a las Urgencias) y la Rede de Atenção às Urgências (Red de Atención a las Urgencias). Resultados: Las facilidades de la contrarreferencia corresponden a las estrategias de comunicación con la Atención Básica: acogida; buenas relaciones interpersonales; y el pronombre electrónico en red. Las dificultades están relacionadas con las deficiencias de la Atención Básica y de los servicios especializados, como el cuantitativo insuficiente de médicos y la demora en la programación de consultas y de exámenes más complejos. Consideraciones finales: Las dificultades evidenciadas indican expresivos desafíos del sistema de salud local en la búsqueda de la integración entre los puntos de atención a las urgencias.

Descriptores: Investigación en Servicios de Salud; Servicios Médicos de Urgencia; Derivación y Consulta; Enfermería; Enfermería de Urgencia. 


\section{INTRODUCTION}

Integration between the different levels of care represents a challenge for health systems worldwide ${ }^{(1)}$, given the problems of articulation between the services with the lowest and highest technological density found in Brazil ${ }^{(2-6)}$ and in other countries ${ }^{(7-8)}$, an aspect related, in part, to the fragmentation of Health Care ${ }^{(4,9)}$.

In this context, considering the need to strengthen the integration of the Brazilian Unified Health System (SUS - Sistema Único de Saúde) services, a National Regulatory Policy was instituted in 2008, which, through Regulação do Acesso à Assistência (Regulation of Access to (are) organizes, controls, manages and prioritizes access and care flows ${ }^{(10)}$. In addition, since 2011, the system started to be organized into Health Care Networks (RAS - Redes de Atenção à Saúde), among which the Urgency and Emergency Network (RUE - Rede de Urgências e Emergências) ${ }^{(11)}$.

Due to its complexity and service characteristics (clinical, surgical, trauma, mental health, among others), RUE is constituted by points of attention necessary to the various actions of service to urgencies and emergencies. These points need to act in an integrated, articulated and synergistic way, with embracement, information and regulation of access being present ${ }^{(12)}$.

Among the points of attention of the RUE, stand out the Emergency Care Units (UPAs - Unidades de Pronto Atendimento) that, depending on the population of the area covered, can be classified as Size I, II or III. Size I UPA is one that has a population of 50 to 100 thousand inhabitants in its area of coverage, while Size II and III are those that have, respectively, a population of 100,001 to 200 thousand and of 200,001 to 300 thousand inhabitants ${ }^{(13)}$.

UPAs are structures of intermediate complexity between the Basic Health Units, Family Health Units and hospitals. The service in the UPA provides, through pacts and predefined flows, that users are counter-referred to points of attention of lower technological density, including Primary Care or specialized, in order to ensure the continuity of care ${ }^{(12)}$.

The way counter-referral occurs, that is, the transfer of information about users between services, varies according to the reality of municipalities or health regions, through traditional instruments such as manual sheets /forms of referral ${ }^{(1,9)}$, printed medical reports, telephone contact or more current information and communication means, such as the electronic system (E-health) that interconnects services and allows access to electronic medical records $\mathrm{s}^{(5)}$.

Thus, if performed in an effective and coherent way, counterreferral favors the integration of network services ${ }^{(2)}$, and communication is an indispensable factor, since it allows the link between the points of attention ${ }^{(14)}$. On the other hand, if it occurs inappropriately, the counter-referral becomes an important barrier to the continuity of care between the different levels of attention ${ }^{(1,14)}$.

In this sense, the health services signal the counter-referral malfunction in the RUE, with losses to the population that does not guarantee their right to an integral health, as revealed in studies developed in Paraná(5), São Paulo ${ }^{(15-16)}$, Minas Gerais ${ }^{(1)}$ and Paraíba ${ }^{(9)}$ States. In view of the above, considering the relevance of the integration between the points of attention of the RUE and the need for research that describes the experiences on the subject in different Brazilian States and municipalities ${ }^{(17)}$, this research was proposed.

\section{OBJECTIVE}

This study aims to describe the facilities and difficulties of the counter-referral of an Emergency Care Unit in Santa Catarina State.

\section{METHOD}

\section{Ethical aspects}

This study was approved by the Research Ethics Committee (CEP - Comitê de Ética em Pesquisa) of the Universidade Federal de Santa Catarina (UFSC). All the participants signed the Free and Informed Consent Term.

\section{Type of study and Theoretical-methodological framework}

A descriptive study, with a qualitative approach, that used the National Policy on Emergency Care (PNAU - Política Nacional de Atenção às Urgências), instituted in 2003 and reformulated in $2011^{(11)}$, and the Health Care Networks ${ }^{(18)}$, with a focus on the Urgency and Emergency Network (RUE - Rede de Atenção às Urgências). This network consists of eight components, especially UPAs, which should articulate and integrate all health equipment to expand and qualify access to urgency and emergency services in health services in an agile and timely manner ${ }^{(11)}$.

The study, piece of a doctoral thesis, is linked to the anchor project 'Organization of Emergency Care Units of the State of Santa Catarina: with the word managers, health professionals and users' developed by the Laboratory of Caring of People in Critical Health Situation (GEASS - Laboratório de Pesquisas no Cuidado de Pessoas em Situações Agudas de Saúde), Graduate Program in Nursing, Universidade Federal de Santa Catarina (UFSC).

\section{Methodological procedures}

An interview script was drawn up which contemplated the characteristics of the participants (age, race, sex, professional category, length of service, year of graduation, complementary training, other employment relationships) and two open-ended questions, one on the counter-referral facilities in UPA and the other, referring to the difficulties.

\section{Study setting}

Research developed in an Emergency Care Unit of a municipality in the region of Greater Florianópolis, Santa Catarina State. The UPA, inaugurated in 2012 and classified as Size I, was selected due to the consolidated experience of implementing this type of service. The selection criteria were the minimum working time of two years and the proven qualification of the institution by means of Ministerial Ordinance.

\section{Data source}

Of the total of 10 nurses and 24 physicians working at the UPA, 20 participated in the study because they met the inclusion criteria: being a nurse or physician with any type of employment relationship and minimum work of three months in the institution, 
considered necessary time to know the organization of the service in relation to the users' counter-referral. Professionals who were on vacation, leave or withdrawal of the activities at the UPA at the time of data collection were excluded. Also excluded were nurses who only acted in the risk classification, since they did not perform counter-referral actions in the UPA. Thus, 14 professionals did not participate; one for dismissal, one for refusal, two for acting only on the classification of risk and 10 because the testimonies report only the facilities and difficulties of referring users to hospitals.

\section{Data collection}

The data collected from November 8, 2015 to February 21, 2016, through a semi-structured individual interview, performed and recorded by one of the researchers, in a private place of the UPA, were transcribed in full by the same. The collection ended when all the professionals who met the eligibility criteria were interviewed.

\section{Organization and analysis of data}

The data were organized and analyzed using the Discourse of the Collective Subject (DCS) technique, which allows for the analysis of the content of the testimonies to include senses or meanings incorporated in them. This technique comprises four methodological figures: Key Expressions (KE); Central Idea (Cl); Anchorage (AC); and DCS itself. KE is defined as excerpts from speech, continuous or not, selected by the researcher because they contain the essence of the content of the testimony. The $\mathrm{Cl}$ is understood as the name or linguistic expression that translates the meaning of each homogeneous set of $\mathrm{KE}$, in a synthetic and precise way. The KE meeting that has the same $\mathrm{Cl}$, in a single speech/synthesis, makes up the DCS. AC is the expression of a theory or ideology embodied in the testimony as if it were an affirmative ${ }^{(19)}$.

Thus, in the process of analysis of the statements, initially, the KE of each testimony were identified. Each set of KE with the same sense generated an IC, the similar IC being grouped into a single one. Finally, DCS were constructed from KE of the same $\mathrm{Cl}$, written in the first person singular ${ }^{(19)}$. AC was not revealed in the testimonials.

In the analysis, besides the qualitative methodological procedure of the DCS already described, the quantitative was used, distinguishing the participant at the end of each speech by the letter "P", followed by the number corresponding to the order of the interviews (P1, P2, ... P20). In the organization and processing of the data, we used the QualiquantiSoft Software of DCS version 1.3c. Brazil, 2015-2016

\section{RESULTS}

Of the 20 professionals participating in the study, 17 (85\%) are physicians and three $(15 \%)$ are nurses, half female $(n=10$; $50 \%)$, predominantly between 31 and 40 years old ( $n=9 ; 45 \%)$. The majority $(n=11 ; 55 \%)$, both physicians and nurses, reported having two or more years of onsite work. Half ( $n=10 ; 50 \%)$ completed the undergraduate course from two to eight years and the majority ( $n=13 ; 65 \%)$ of them had some complementary training, especially Residencies and Specializations. It was verified that $75 \%(n=15)$ of the professionals work in one or more places besides the UPA. Of the nurses, only one (5\%) work in another service, and of the total number of physicians, 14 (70\%) work in other establishments, in addition to UPA.

From the testimonies of the professionals, three discourses and their respective Central Ideas (Cls) emerged, the first one (DCS1) referring to the facilities of the counter-referral, while the second and third, the difficulties (DCS2 and DCS3) (Figure 1).

The DCS1 was constituted of the testimonies of nine participants (45\%). It deals with the facilities identified by UPA professionals when performing the users' counter-referral for Primary Care, facilities that are understood as communication strategies existing in the Basic Health Unit (BHU), such as embracement, or between services, BHU and UPA, such as good interprofessional relationships and the electronic medical record network (Figure 1).

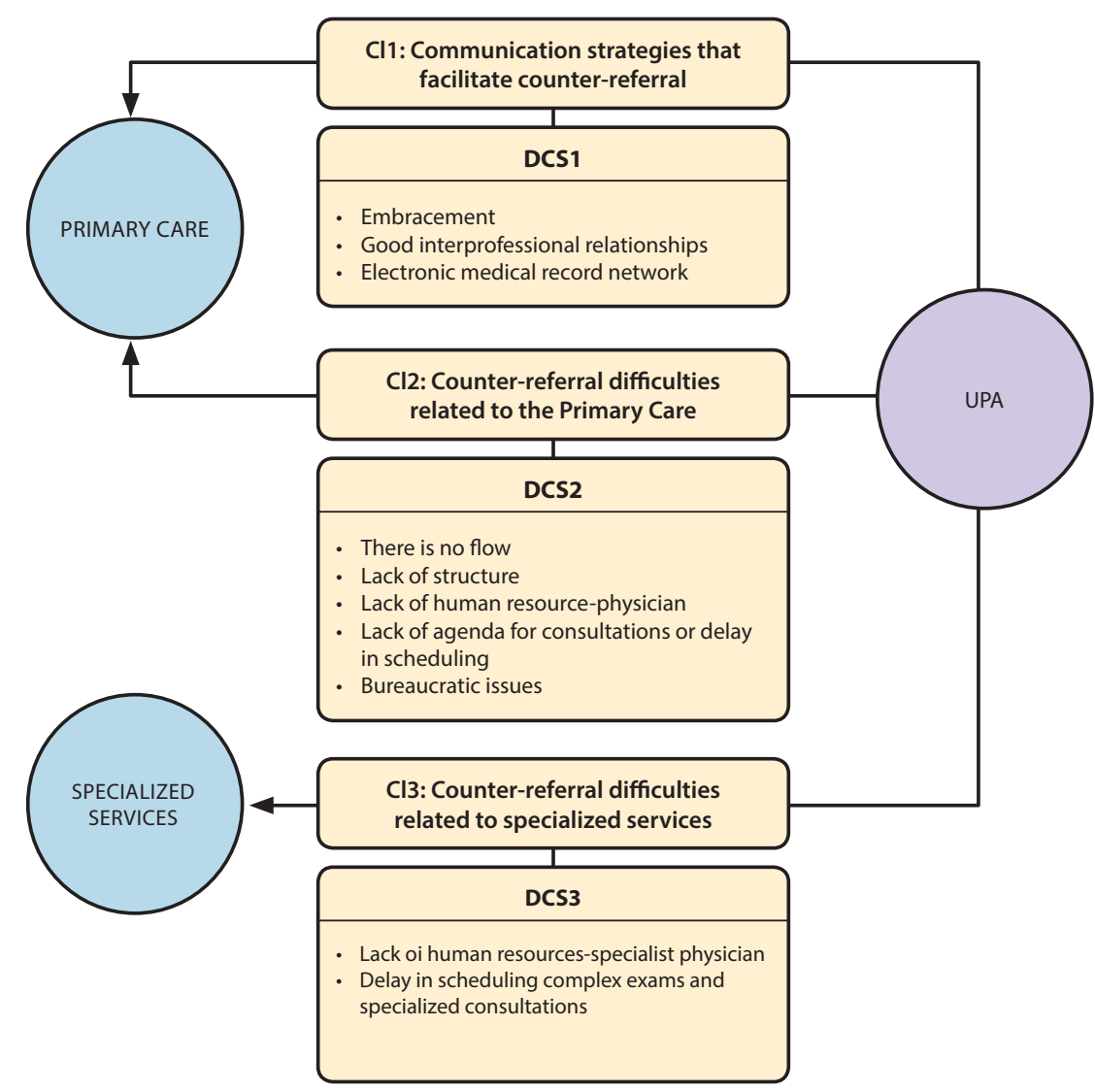

Figure 1 - Facilities and difficulties of counter-referral at an UPA, Florianópolis, Santa Catarina, 


\section{CI1: Communication strategies that facilitate counter- referral - embracement, good interprofessional relations and electronic medical record network}

\begin{abstract}
DCS1: I consider it as a counter-referral facility the very way in which the Family Health Strategy works, which proposes to welcome the patient, the team has that spirit [...] Anotherfacility for me is to know, to have good ones contacts with staff. Having a contact facilitates everything [...] A great advantage is our system that is all integrated, the UPA and Basic Units have a program that works very well, via internet, we can both access what the health center wrote in the electronic medical record as they can see what the conduct was here, so whatever I note, evolve here, will fall into the Basic Unit and the professional there will be able to see what happened, what medications were used and from there to take a conduct. It is a facility for the electronic medical record, it greatly streamlines our performance, it is not expensive and the gain for the patient is very large [...] When the patient is from the municipality, it facilitates the fact that the system is the same. (P1, P5, P6, P13, P16, P17, P18, P19, P20)
\end{abstract}

The DCS2, composed by most participants ( $n=16 ; 80 \%)$, presents the difficulties revealed by professionals regarding counter-referral, which are related to the deficiencies of Primary Care (PC), which involves lack of flow, of human resources, mainly medical, health unit structure, as well as bureaucratic issues (Figure 1).

\section{$\mathrm{Cl2}$ : Counter-referral difficulties related to the Primary Care}

DCS2: I realize that the counter-referral basically does not exist, it's very rudimentary, there's no flow, no drawing, no such path to the basic network. The UPA does not work as part of a network yet. We are already more advanced [...] than the electronic medical record, but there is stillmissing a better relationship between services. Primary Care is complicated by lack of human resource, structure, lack of agenda [...], as well as bureaucratic issues. [...] Patients say that because of a lack of physicians and because of the delay in care, they do not go to the clinic, and that means they always come back to the UPA. [...] They come to the UPA because they are sure, they know they will be taken care of, they will come out with treatment, so most come here because of practicality, convenience. The vastmajority of patients seen here are of low complexity, but we cannot deny the care or send them back, they are all taken care of [...].With regard to cases of pediatrics, the counter-referral [...] is a little exhausting for the patient who does not have a vacancy to be replaced [...] then I do not even refer anymore because they say that they do not have a pediatrician. [...] (P2, P3, P4, P5, P7, P8, P9, P10, P11, P12, P14, P15, P16, P17, P18, P19)

The DCS3, which is less representative in terms of number of statements ( $n=3 ; 15 \%)$, presents the difficulties faced by UPA professionals in the counter-referral of users to specialized services, which refer to the more complex exams and ambulatory services required by the medical professional. These difficulties involve the delay in the scheduling of the examinations and the consultations or the non-scheduling of these for lack of medical specialists (Figure 1).

\section{CI3: Counter-referral difficulties related to specialized services}

DCS3: When the patient needs a more complex examination, an ultrasound, tomo, resonance, he finds difficulties because it takes time to schedule; depending on the specialty that the person needs, it also takes [...] there is no specialist to refer, the patient is left not served or goes to the private service. [...] then he comes to the UPA and we do the treatment, he improves, he tries to follow up with the specialist, but he does not get the consultation. For example, a patient with epilepsy who arrives every week with a seizure, we explain that he has to be accompanied by the neurologist, and he says: Ah, I'm waiting. So you have these basic network problems. (P13, P17, P18)

\section{DISCUSSION}

The characteristics of the participants of this study may be favorable to the elucidation of the counter-referral between UPA and RUE services, among which the age group (31 to 40 years), the duration of the UPA (two to four years), graduation time (at least two years), complementary training and assessment at other levels of the network. Therefore, it is a relatively young group, recently graduated from undergraduate and/or graduate studies, with an up-to-date view of the health system. Similar results were found with respect to complementary training, at residency and specialization levels, in a study performed with physicians and nurses at UPAs in Rio de Janeiro(20).

In the analysis of the first speech, which deals with the facilities found in the counter-referral, the embracement performed on the user in Primary Care can be understood as a communication strategy that facilitates counter-referral between UPA and BHU. In this sense, embracement becomes a powerful space for the humanization of health services, through qualified listening to the user, identification of their needs and a team work to solve their problem. Embracement is therefore an inherent tool not only for the work on the Family Health Strategy (FHS), but also guides and facilitates the organization of work in UPAs ${ }^{(21-22)}$. In the perspective of good practices in PC, embracement becomes a point of intersection between different subjects and care practices, unfolding in dimensions, such as dialogue, posture and reorganization of services, triggering transformations in the work process, relationships established in the care space and at the organizational level(23).

The good interpersonal relationships among professionals from different points of the RUE as a strategy for the referral of the user from one service to the other are also a facility to access services at other levels. In the integration of UPAs with the assistance network, personal contact is the prevailing practice ${ }^{(4)}$, and in Regulatory Centers, despite the normative process, some situations can occur through the network of personal relationships, such as parallel flows, created for the effective of professional action ${ }^{(24)}$. Studies corroborate interpersonal relationships as alternative practices due to poor communication for integration between services ${ }^{(4,24)}$.

Thus, although participants emphasize good interpersonal relationships as a counter-referral facility, this type of practice used to enable the user's pathway between health care points is an informal strategy of integration between services that, in a way as it is being carried out, signals the difficulties of the emergency care network.

In the first discourse, the electronic medical record in the network emerged as a tool that can facilitate intercommunication in 
the points of attention. The emphasis of this facilitator lies in the recognition by UPA professionals that their network deployment has promoted access to the patient's health history served at the $\mathrm{BHU}$. However, the electronic medical record is restricted to the municipal territory, which includes all BHUs, but the UPA is part of a micro-regional territory. When the user resides in the UPA's headquarters, the electronic medical record facilitates the local counter-referral, however, for the user of another municipality that accesses the same UPA, in which the professionals have no means of triggering the background for a more integral approach of the care, becomes a limiting aspect to the counter-referral.

In the municipality in question, the electronic medical record system used is called the Triple Electronic Health Record (Triple EHC). In Curitiba, Paraná State, health establishments use the E-health electronic system, which functions as a reference and counter-referral tool and interconnects municipal health services ${ }^{(5)}$. On the other hand, there are studies that show the lack ${ }^{(25)}$ and/or absence ${ }^{(26)}$ of electronic medical records in health facilities, being the user, in most cases, the main interlocutor of information between the different levels of attention, fact that generates a precarious communication between the attention levels and the discontinuity in the care.

However, it is important to note that the implementation of an electronic medical record throughout the country is essential to improve the quality of care ${ }^{(25)}$, since electronic health records would enhance patient care and clinical management ${ }^{(27)}$. An Australian study has shown that its adoption is quite low, used predominantly in hospitals, although it continues to grow and significantly, increasingly present in Primary Care ${ }^{(27)}$, as also national studies show ${ }^{(5,28)}$. In Brazil, this type of communication has been encouraged with the implementation of the Health Information System for Primary Care (SISAB - Sistema de Informação em Saúde para a Atenção Básica), operationalized through the e-SUS Primary Care strategy (e-SUS AB) ${ }^{(29-30)}$.

In the analysis of the second discourse, the set of difficulties (lack of flow, lack of human resources - physicians, structure, scheduling and bureaucratic issues) faced by UPA professionals in the counter-referral interferes in the understanding of PC as a gateway priority and coordination of the care system. This can be perceived when users use UPA care to resolve complaints that could, at least initially, be met at the first level of care, forcing the UPA to function as the receiving unit of PC demands along with the provision of care to situations and acute and urgent aggravations, which are their reason for existing. The UPAs seem to accept a suppressed demand that comes from the lack of service provision and the restriction of PC's working hours ${ }^{(4,31-32)}$.

Considering that UPAs should articulate with PC and diagnostic and therapeutic support units by constructing and ordering coherent and effective counter-referral flows ${ }^{(11)}$, the definition of such service flows and counterflows is critical to providing access and care continued. In this sense, the UPAs as urgency and emergency services, when well-articulated in the network, strengthen PC's action ${ }^{(31)}$.

For practitioners, PC deficiencies culminate in the absence of counter-referral from both the adult and pediatric populations, as the second discourse shows. A study evaluating care for children under two years of age at the FHS also revealed a lack of counter-referral, as well as mismatch between needs and service offerings ${ }^{(33)}$. For most professionals, the counter-referral for PC does not happen, it is deficient, which signals fragmentation in health care $^{(34)}$.

The lack of flow of users to PC, revealed in DCS2, is corroborated by the literature. In the city of Rio de Janeiro, during the daytime period, when the PC and UPA services are functioning, there is no specific communication format, there are no formal flows to counter referrals to UPA patients ${ }^{(4)}$. In Florianópolis, Santa Catarina States, the lack of definition of counter-referral flows is one of the limitations of a network service ${ }^{(31)}$.

However, the counter-referral difficulties of the users served in the UPA are related not only to PC, but also to specialized services, as evidenced in DCS3. This discourse, although less representative by the number of testimonies that constituted it, is highly significant for the understanding of counter-referral difficulties in RUE, since they constitute barriers to access to specialized attention, which limit the degree of integration between services, with consequent fragmentation of care ${ }^{(1)}$. The difficulties expressed in this discourse, which involve prolonged waiting time and/or the insufficient supply of specialized medical examinations and consultations, have been identified in other realities of the country, such as São Paulo(35), Minas Gerais ${ }^{(1)}$, Bahia ${ }^{(32)}$ and Pernambuco ${ }^{(36-37)}$ States, which indicates important counter-referral problems in the health care of the population.

However, difficulties of access to specialized care are not unique to the country. Prolonged waiting time, especially for specific exams such as imaging and for consultations with specialists, were evidenced in Spain ${ }^{(8)}$ and Canada ${ }^{(38-39)}$, respectively, which caused interruptions in the diagnosis and treatment process, and the search for private health care ${ }^{(8)}$, also revealed in the present research.

While meeting the demands of procedures and consultations is promoted through the user's embracement in the $\mathrm{BHU}$, as manifested in DCS1, the pursuit of continuity of care may be impaired when there is a need to access the specialized services, as consultations, examinations and procedures in these services are offered by municipal quotas, through Agreed and Integrated Programming (PPI - Programação Pactuada Integrada), calculated by the offer and not by the population's need. PPI is delimited by levels of complexity of the service network and, in order for access to take place, it is necessary to comply with the reference flows, the supply through regulation, considering the installed physical capacity ${ }^{(9)}$ of public and private providers, as well as the physical and financial quota established.

Thus, in the professionals' discourse, difficult access to specialized services in the public health system, in a sense, directs users to supplementary health care through private health plans, a sector that plays a crucial role in the provision of services, and which develops due to the existence of a health services market which is not regulated or regulated by the government incompletely ${ }^{(40)}$. The analysis of access to specialized services makes it possible to affirm that attention of medium complexity is the bottleneck of SUS at present ${ }^{(41)}$ and that it requires special attention from managers of the public health system.

\section{Study limitations}

The study, limited to the participation of physicians and nurses of an UPA, does not allow the generalization of the results. In 
addition, the greater number of physicians in relation to nurses may have directed the findings to the biomedical perspective, especially regarding the difficulties of the counter-referral, with emphasis on medical and specialized health care, focusing on the disease. However, care was taken to invite all medical professionals and nurses from the service to participate in the research.

\section{Contributions to the sectors of Nursing, Health or Public Policy}

The study indicates that the difficulties of the UPA counterreferral do not directly involve Nursing and that this may be present in the communication strategies that facilitate the counter-referral, mainly by the embracement in Primary Care. The results will be able to subsidize improvements in the municipality and region in relation to the counter-referral of the UPA and the facilities listed therein, if applied in other realities of the state or country, being able to favor the consolidation of the RUE, respecting the peculiarities of the different contexts. In addition, the study expands the knowledge on the subject at the national level and allows for reflection by the managers and formulators of the PNAU, contributing to its improvement, as well as the RUE.

\section{FINAL CONSIDERATIONS}

The counter-referral facilities in the UPA correspond to the strategies of communication with Primary Care: embracement; good interpersonal relationships; and electronic medical record in network. In relation to the difficulties, these are linked to the deficiencies of Primary Care and specialized services. In Primary Care, there are insufficient physicians, structural problems, scheduling of consultations and bureaucratic issues, whereas in specialized services, more complex examinations and consultations are compromised by delay in scheduling or by the lack of medical specialists.

The analysis of the counter-referral in an UPA of the region of Greater Florianópolis allowed identifying that the difficulties in the same were revealed by a greater number of professionals when compared to the facilities, indicating that the challenges are expressive in the search of the integration between the points of attention to the urgencies.

Further investigations with health professionals from other points of the emergency network (Primary Care and specialized services) may allow confrontation of the results listed and deepen the knowledge produced about the counter-referral.

\section{FUNDING}

Research funded by the Fundação de Amparo à Pesquisa e Inovação do Estado de Santa Catarina (FAPESC), through Public Notice 007/2013 - Research for the SUS, and by the Coordination for the Improvement of Higher Education Personnel (CAPES - Coordenação de Aperfeiçoamento de Pessoal de Nível Superior), which granted scholarship to one of the authors during her Doctorate for the development of the study.

\section{REFERENCES}

1. Vieira EW, Gazzinelli A. [Degree of integration of Primary Health Care of a small municipality in the Health Services Network]. Saúde Soc [Internet]. 2017 [cited 2017 Dec 20];26(2):448-61, 2017. Available from: http://dx.doi.org/10.1590/s0104-12902017170100 . Portuguese.

2. Costa JP, Jorge MSB, Vasconcelos MGF, Paula ML, Bezerra IC. [Solvability of the caretaking in primary care: multiprofessional articulation and services network]. Saúde Debate [Internet]. 2014 [cited 2017 Nov 15];38(103):733-43. Available from: http://dx.doi.org/10.5935/01031104.20140067. Portuguese.

3. Almeida PF, Santos AM, Santos VP, Silveira Filho RM. Care integration in a health region: a paradox between regional needs and local interests. Saúde Soc [Internet]. 2016 [cited 2017 Dec 28];25(2):320-35. Available from: http://dx.doi.org/10.1590/S0104-12902016153295 . English, Portuguese.

4. Konder MT, O'Dwyer G. [The integration of the Emergency Care Units (UPA) with healthcare services in the city of Rio de Janeiro, Brazil] Interface [Internet]. 2016 [cited 2017 Nov 30];20(59):879-92. Available from: http://dx.doi.org/10.1590/1807-57622015.0519 Portuguese.

5. Uchimura LYT, Viana ALD, Silva HP, Ibañez N. [Emergency Care Units (UPAs): management features to the care networks in Paraná]. Saúde Debate [Internet]. 2015 [cited 2017 Nov 30];39(107):972-83. Available from: http://www.scielo.br/pdf/sdeb/v39n107/0103-1104sdeb-39-107-00972.pdf. Portuguese.

6. O'Dwyer G, Konder MT, Reciputti LP, Lopes MGM, Agostinho DF, Alves GF. The process of implementation of emergency care units in Brazil. Rev Saúde Pública [Internet]. 2017 [cited 2017 Dec 28];51:125. Available from: http://dx.doi.org/10.11606/s1518-8787.2017051000072

7. Urada D, Teruya C, Gelberg L, Rawson R. Integration of substance use disorder services with primary care: health center surveys and qualitative interviews. Subst Abuse Treat Prev Policy [Internet]. 2014 [cited 2017 Dec 17];9:15. Available from: https://www.ncbi.nlm.nih.gov/ pmc/articles/PMC3978198/pdf/1747-597X-9-15.pdf

8. Waibel S, Vargas I, Aller MB, Coderch J, Farré J, Vázquez ML. Continuity of clinical management and information across care levels: perceptions of users of different healthcare areas in the Catalan national health system. BMC Health Serv Res [Internet]. 2016 [cited 2017 Dec 26];16:466. Available from: https://www.ncbi.nlm.nih.gov/pmc/articles/PMC5010665/pdf/12913_2016_Article_1696.pdf

9. Protasio APL, Silva PB, Lima EC, Gomes LB, Machado LS, Valença AMG. [Evaluation of the reference and counter-reference system based on the responses of the Primary Care professionals in the first External Evaluation cycle of PMAQ-AB in the state of Paraíba]. Saúde Debate [Internet]. 2014 [cited 2017 Oct 20];38(Spec):209-20, 2014. Available from: http://dx.doi.org/10.5935/0103-1104.2014S016. Portuguese. 
10. Ministério da Saúde (BR), Gabinete do Ministro. Portaria n. 1.559, de $1^{\circ}$ de Agosto de 2008. Institui a Política Nacional de Regulação do Sistema Único de Saúde - SUS [Internet]. Diário Oficial da União: República Federativa do Brasil; 2008 [cited 2017 Dec 30]. Jul 8, Seção 1: p. 48. [about 06 screens]. Available from: http://bvsms.saude.gov.br/bvs/saudelegis/gm/2008/prt1559_01_08_2008.html

11. Ministério da Saúde (BR). Portaria n. 1.600, de 07 de Julho de 2011. Reformula a Política Nacional de Atenção às Urgências e institui a Rede de Atenção às Urgências no Sistema Único de Saúde (SUS) [Internet]. Diário Oficial da União: República Federativa do Brasil; 2011 [cited 2017 Dec 30]. Oct 06, Seção 1: p. 56. [about 03 screens]. Available from: http://bvsms.saude.gov.br/bvs/saudelegis/gm/2011/ prt1600_07_07_2011.html

12. Ministério da Saúde (BR), Secretaria de Atenção à Saúde, Departamento de Atenção Especializada. Manual instrutivo da Rede de Atenção às Urgências e Emergências no Sistema Único de Saúde (SUS) [Internet]. Brasília: Ministério da Saúde; 2013 [cited 2017 Dec 10]. 86 p. Available from: http://bvsms.saude.gov.br/bvs/publicacoes/manual_instrutivo_rede_atencao_urgencias.pdf

13. Ministério da Saúde (BR), Gabinete do Ministro. Portaria n. 104, de 15 de Janeiro de 2014. Altera a Portaria n. $342 / G M / M S$, de 04 março de 2013, que redefine as diretrizes para implantação do Componente Unidade de Pronto Atendimento (UPA 24h) e do conjunto de serviços de urgência 24 (vinte e quatro) horas não hospitalares da Rede de Atenção às Urgências e Emergências (RUE), em conformidade com a Política Nacional de Atenção às Urgências, e dispõe sobre incentivo financeiro de investimento para novas UPA 24h (UPA Nova) e UPA 24h ampliadas (UPA Ampliada) e respectivo incentivo financeiro de custeio mensal [Internet]. Diário Oficial da União: República Federativa do Brasil; 2014 [cited 2017 Dec 30]. Mar 04, Seção 1: p. 47. [about 06 screens]. Available from: http://bvsms.saude.gov.br/bvs/saudelegis/ gm/2014/prt0104_15_01_2014.html

14. Kantorski LP, Coimbra VCC, Oliveira NA, Nunes CK, Pavani FM, Sperb LCSO. Psychosocial attention of children and adolescents: interfaces with the health network by the referral and counter-referral system. Texto Contexto-Enferm [Internet]. 2017 [cited 2017 Dec 28];26(3):e1890014. Available from: http://dx.doi.org/10.1590/0104-07072017001890014. English, Portuguese.

15. Garcia VM, Reis RK. [Profile of users assisted in a non-hospital emergency unit]. Rev Bras Enferm [Internet]. 2014 [cited 2017 Oct 15];67(2):261-67. Available from: http://dx.doi.org/10.5935/0034-7167.20140035. Portuguese.

16. Bousquat A, Giovanella L, Campos SEM, Almeida PF, Martins CL, Mota PHS, et al. Primary health care and the coordination of care in health regions: managers' and users' perspective. Ciênc Saúde Colet [Internet]. 2017 [cited 2017 Dec 20];22(4):1141-54. Available from: http:// dx.doi.org/10.1590/1413-81232017224.28632016. English, Portuguese.

17. O'Dwyer G, Konder MT, Machado CV, Alves CP, Alves RP. The current scenario of emergency care policies in Brazil. BMC Health Serv Res [Internet]. 2013 [cited 2017 Dec 10];13:70. Available from: https://www.ncbi.nlm.nih.gov/pmc/articles/PMC3598552/pdf/1472-6963-13-70. pdf

18. Mendes EV. [Comments about Health Care Networks in SUS]. Divulg Saúde Debate [Internet]. 2014 [cited 2017 Dec 30];(52):38-49. Available from: http://cebes.org.br/site/wp-content/uploads/2014/12/Divulgacao-52.pdf. Portuguese.

19. Lefévre F, Lefévre AM. Pesquisa de representação social: um enfoque qualiquantitativo: a metodologia do discurso do sujeito coletivo. 2 ed. Brasília: Liber Livro; 2012. 224 p.

20. Machado CV, Lima LD, O'Dwyer G, Andrade CLT, Baptista TWF, Pitthan RGV, et al. [Workforce management in Emergency Care Units: government strategies and profile of healthcare professionals]. Cad Saúde Pública, 2016 [cited 2017 Dec 20];32(2):e00170614. Available from: http://dx.doi.org/10.1590/0102-311X00170614. Portuguese.

21. Costa PCP, Garcia APRF, Toledo VP. Welcoming and nursing care: a phenomenological study. Texto Contexto Enferm [Internet]. 2016 [cited 2017 Dec 28];25(1):e4550015. Available from: http://dx.doi.org/10.1590/0104-07072016004550014 . English, Portuguese.

22. Machado LM, Colomé JS, Silva RM, Sangoi TP, Freitas NQ. The meaning of professional making at family health strategy: primary care as scenario practice. Rev Pesqui Cuid Fundam [Internet]. 2016 [cited 2017 Dec 10];8(1):4026-35. Available from: http://www.seer.unirio.br/ index.php/cuidadofundamental/article/view/3384/pdf_1829

23. Guerrero P, Mello ALSF, Andrade SR, Erdmann AL. User embracement as a good practice in primary health care. Texto Contexto-Enferm [Internet]. 2013 [cited 2017 Nov 20];22(1):132-40. Available from: http://dx.doi.org/10.1590/S0104-07072013000100016. English, Portuguese.

24. Gawryszewski ARB, Oliveira DC, Gomes AMT. [Access to SUS: representations and practices of professionals developed in regulation centers]. Physis [Internet]. 2012 [cited 2017 Dec 11];22(1):119-40. Available from: http://dx.doi.org/10.1590/S0103-73312012000100007. Portuguese.

25. Gonçalves JPP, Batista LR, Carvalho LM, Oliveira MP, Moreira KS, Leite MTS. [Electronic Medical Record: a tool that can contribute to integration of Health Care Networks]. Saúde Debate [Internet]. 2013 [cited 2017 Dec 11];37(96):43-50. Available from: http://dx.doi. org/10.1590/S0103-11042013000100006. Portuguese.

26. Santos AM, Giovanella L. [Family health strategy in care coordination in a health administrative region in Bahia, Brazil]. Saúde Debate [Internet]. 2016 [cited 2017 Nov 30];40(108):48-63. Available from: ttp://dx.doi.org/10.1590/0103-1104-20161080004. Portuguese.

27. Nguyen L, Bellucci E, Nguyen LT. Electronic health records implementation: an evaluation of information system impact and contingency factors. Int J Med Inform [Internet]. 2014 [cited 2017 Oct 30];83(11):779-96. Available from: http://www.sciencedirect.com/science/article/ pii/S1386505614001233?via\%3Dihub

28. Sisson MC, Andrade SR, Giovanella L, Almeida PF, Fausto MCR, Souza CRP. [Family Health Strategy in Florianópolis: integration, coordination and position in the local healthcare network]. Saúde Soc [Internet]. 2011 [cited 2017 Oct 20];20(4):991-1004. Available from: http://dx.doi. 
Counter-referral in Emergency Care Units: discourse of the collective speech Hermida PMV, Nascimento ERP, Echevarría-Guanilo ME, Andrade SR, Ortiga AMB.

org/10.1590/S0104-12902011000400016. Portuguese.

29. Oliveira AEC, Lima IMB, Nascimento JA, Coelho HFC, Santos SR. [Implementation of e-SUS AB in Sanitary District IV of João Pessoa (PB): experience report]. Saúde Debate [Internet]. 2016 [cited 2017 Dec 20];40(109):212-18. Available from: http://dx.doi.org/10.1590/01031104201610917. Portuguese.

30. Medeiros JB, Holmes ES, Albuquerque SGE, Santos SR. O e-SUS Atenção Básica e a coleta de dados simplificada: relatos da implementação em uma Estratégia Saúde da Família. Rev APS [Internet]. 2017 [cited 2017 Dec 28];20(1):145-9. Available from: https://aps.ufjf.emnuvens. com.br/aps/article/view/2706/1070

31. Erdmann AL, Andrade SR, Mello ALSF, Drago LC. Secondary health care: best practices in the health services network. Rev Lat Am Enfermagem [Internet]. 2013 [cited 2017 Nov 10]; 21(Spec):131-9. Available from: http://dx.doi.org/10.1590/S0104-11692013000700017. English, Portuguese.

32. Santos AM, Giovanella L. [Managing comprehensive care: a case study in a health district in Bahia State, Brazil]. Cad Saúde Pública [Internet]. 2016 [cited 2017 Nov 15];32(3):e00172214. Available from: http://dx.doi.org/10.1590/0102-311X00172214. Portuguese.

33. Silva AS, Fracolli LA. Evaluating child care in the Family Health Strategy. Rev Bras Enferm [Internet]. 2016 [cited 2017 Dec 15];69(1):54-61. Available from: http://dx.doi.org/10.1590/0034-7167.2016690107i. English, Portuguese.

34. Costa SM, Ferreira A, Xavier LR, Guerra PNS, Rodrigues CAQ. Referência e contrarreferência na saúde da família: percepção dos profissionais de saúde. Revista APS [Internet]. 2013 [cited 2017 Nov 20];16(3):287-93. Available from: https://aps.ufjf.emnuvens.com.br/aps/article/ view/1888/746

35. Marin MJS, Marchioli M, Moracvick MYAD. Strengths and weaknesses of the care delivered in the traditional primary healthcare units and family healthcare strategy units in the perspective of users. Texto Contexto-Enferm [Internet]. 2013 [cited 2017 Dec 20];22(3):780-8. Available from: http://dx.doi.org/10.1590/S0104-07072013000300026. English, Portuguese.

36. Albuquerque MSV, Lyra TM, Farias SF, Mendes MFM, Martelli PJL. [Accessibility to health services: an analysis of the Primary Care in the state of Pernambuco]. Saúde Debate [Internet]. 2014 [cited 2017 Dec 26];38(Esp):182-94. Available from: http://dx.doi.org/10.5935/01031104.2014S014. Portuguese.

37. Sousa FOS, Medeiros KR, Gurgel Júnior GD, Albuquerque PC. [From normative aspects to the reality of the Unified Health System: reavealing barriers that curtail access to the health care network]. Ciênc Saúde Colet [Internet]. 2014 [cited 2017 Oct 20];9(4):1283-93. Available http:// dx.doi.org/10.1590/1413-81232014194.01702013. Portuguese.

38. Harrington DW, Wilson K, Rosenberg M, Bell S. Access granted! barriers endure: determinants of difficulties accessing specialist care when required in Ontario, Canada. BMC Health Serv Res [Internet]. 2013 [cited 2017 Dec 27];13:146. Available from: https://bmchealthservres. biomedcentral.com/track/pdf/10.1186/1472-6963-13-146?site=bmchealthservres.biomedcentral.com

39. Jaakkimainen L, Glazier R, Barnsley J, Salkeld E, Lu H, Tu K. Waiting to see the specialist: patient and provider characteristics of wait times from primary to specialty care. BMC Fam Pract [Internet]. 2014 [cited 2017 Dec 27];15:16. Available from: https://www.ncbi.nlm.nih.gov/ pmc/articles/PMC3912928/pdf/1471-2296-15-16.pdf

40. Costa NR. Brazilian healthcare in the context of austerity: private sector dominant, government sector failing. Ciênc Saúde Colet [Internet]. 2017 [cited 2017 Dec 26];22(4):1065-74. Available from: http://dx.doi.org/10.1590/1413-81232017224.28192016. English, Portuguese.

41. Silva CR, Carvalho BG, Cordoni Júnior L, Nunes EFPA. Difficulties in accessing services that are of medium complexity in small municipalities: a case study. Ciênc Saúde Colet [Internet]. 2017 [cited 2017 Dec 26];22(4):1109-20. Available from: http://dx.doi.org/10.1590/141381232017224.27002016. English, Portuguese. 